\title{
Financial Market Integration of South Asian Countries: Panel Data Analysis
}

\author{
Hasan Muhammad Mohsin \\ Pakistan Institute of Development Economics, Quaid-i-Azam University Campus \\ PO Box 1091, Islamabad, Pakistan \\ Tel: (92)-51-924-8080Ｅ-mail: hasanmuhammadmohsin@gmail.com
}

Patrick A. Rivers (Corresponding author)

College of Applied Sciences \& Arts, Southern Illinois University

1365 Douglas Drive -MC 6615, Carbondale, IL 62901

Tel: 618-453-8842Ｅ-mail: privers@siu.edu

Received: July 16, $2010 \quad$ Accepted: August 5, $2010 \quad$ doi:10.5539/ijef.v3n2p65

\begin{abstract}
In order to attain financial integration using the Feldstein Horoika $(\mathrm{FH})$ model, the real interest rates differentials must be short lived. This paper estimates the degree of financial market integration in South Asian countries (i.e., Pakistan, India, Bangladesh, Sri Lanka and Nepal) utilizing both techniques i.e. FH model and Real Interest Rates Differentials (RIDs). This study shows some degree of integration with the FH model which has increased in post liberalization period since the 1990's. The estimates from (RIDs) methodology showed that real interest rates differentials of South Asian countries are found to be stationary when compared with the United States, Canada, United Kingdom, Germany, Sweden, Netherlands, Australia, Malaysia, Indonesia, South Korea, Singapore, China and Japan. The empirical evidence of integration using both techniques is a unique finding in the literature. Even though the RIDs technique provides strong evidence of integration, correlation between savings and investment is still significant.
\end{abstract}

Keywords: Financial Integration, Interest rate parity, Savings investment correlation, South Asian economy

\section{Introduction}

In the era of globalization and information technology, countries have developed a closer bond with each other. The volume of merchandized trade and capital mobility has been enhanced. Investors are able to diversify portfolios by investing capital almost anywhere in the world. Emerging markets are eliminating capital controls and introducing market-friendly policies to attract foreign capital via foreign direct investment or equity. Free and perfect capital mobility is characteristic of highly integrated financial markets.

The degree of capital mobility or financial integration is vital to most macroeconomic models. The degree of market integration can be estimated with interest parity, saving-investment correlations of Feldstein and Horoika (1980) and degree of monetary autonomy (Edwards and Khan, 1985). Frankel (1992) stated that when low correlation between savings and domestic investment exists, real interest must continue. The current study contributes to the literature by applying both these techniques to South Asian countries, a first in the literature. Furthermore liberalization dummies were applied and country slope dummies were estimated to determine if asymmetry in the correlation of savings and investments exists in pre and post liberalization periods.

Feldstein and Horoika (1980) used data from 21 Organization for Economic Cooperation and Development (OECD) countries from 1960-1974 and reported that the domestic savings coefficient in investment implied capital immobility, a controversial finding. Other studies showed similar results (Feldstein, 1983; Penati and Dooley, 1984). Dooley et al. (1987) used data from 64 industrialized and developing countries during 1960-1984 and reported a higher savings coefficient. Bayoumi (1990) also confirmed the results of Horoika (1980) but held government policy responsible for this correlation. Haque and Montiel (1991) estimated degree of financial openness in developing countries and showed higher integration. Yamori (1995) reported a higher savings coefficient but argued that this was due to a non-zero currency premium similar to that seen by Frankel (1991, 1992). Jansen (1996) cited the stationary current account as the rationale behind the findings of Horoika (1980).

Coakley et al. (2001) utilized panel unit roots and cointegration techniques using quarterly data from 12 OECD countries during 1980-2001 and found that savings and investment are integrated of order one, I (1) and generally do 
not cointegrate. Avik (2006) used data from 126 countries and found a positive and significant association between savings and investment. However, this same study showed lower coefficients for non-OECD countries when compared to OECD countries which are surprising. Cooray and Sinha (2007) used data for 20 African countries and showed high correlation using both Johansen and fractional cointegration tests. Adedeji and Thornton (2008) used pooled data for 50 developed and developing countries for the period 1970-2000 and found that savings and investment are non-stationary and cointegrated; however, there were differences in savings retention ratios.

The real interest rate parity hypothesis (RIPH) states that if agents are rational and arbitrage forces are free to act in goods and assets markets, then real interest rates between countries will equalize. According to Ferreira et al. (2007), few studies have tested RIPH via Unit Root analysis on RIDs and the literature does not offer a conclusive answer (Meese \& Rogoff, 1988), (Edison \& Pauls, 1993), (Obsfeld \& Taylor, 2002), (Mancuso, Goodwin, \& Grennes, 2003).

South Asian countries (i.e., Pakistan, Bangladesh, India, Sri Lanka and Nepal) started the financial liberalization process in the early 1990's (Bekaert, Harvay, \& Lundblad, 2001). This region is important since aggregate net flows to this region have increased since the mid-1980's (Hussain \& Jun, 1992). According to Global Development Finance (2006), private capital flows to South Asia have more than doubled since 2000. For example, capital flows reached $\$ 23.6$ billion in 2005, compared to $\$ 9.7$ billion in 2000. In South Asia, the Foreign Direct Investment (FDI) increased to $\$ 8.4$ billion, representing an increase of $\$ 1.2$ billion since last year. The report mentions that India received a major share of capital flows to South Asia. Liberalization efforts in the 1990's as well as the subsequent surge in capital flows to South Asian countries makes them especially interesting to study.

The purpose of this study is to use a panel of South Asian countries to examine integration of financial markets in these countries with two techniques. Furthermore, it will measure the impact of liberalization on integration. The present study also adjusts some of the econometric criticism levied against Feldstein and Horoika (FH, 1980) and observes whether the estimates remain the same when the model is adjusted accordingly.

\section{Patterns of Savings and Investments}

\subsection{Savings and Investments in South Asia}

The FH (1980) model is based primarily on the domestic saving and investment relationship. Thus, it is necessary to observe average savings and investment in South Asian countries. Changes which have occurred in the saving- to GDP ratios (S/Y) and Investment to GDP ratio (I/Y) since 1970 are discussed in this paper. The study provides this information in Table 1. The average saving and investment to GDP ratio in Bangladesh was $10 \%$ and $18 \%$, respectively, average for the period 1970-99. However, in 2000, the S/Y and I/Y increased, thereby decreasing the resultant gap. In India, savings and investment to GDP ratios were high throughout the whole region. Both the ratios showed a stable pattern and a slight increase over decades. The saving-investment gap for India is also lowest in the region estimated to contribute $1.67 \%$ of the GDP, thereby showing very low dependence on foreign capital. It clearly shows that domestic savings could finance most of the domestic investment in India. In Nepal, the saving investment gap was $12.74 \%$ of the GDP during the 2000's, the highest in the region. During the 2000's, the investment to GDP ratio was $23.6 \%$, the highest ever recorded. Average saving and investment to GDP ratio in Pakistan was estimated at 16 and $17.8 \%$, respectively, during the 2000 's. The $\mathrm{S} / \mathrm{Y}$ increased but $\mathrm{I} / \mathrm{Y}$ decreased in the 2000's when compared to the 1990's. However, the savings investment gap decreased sharply in the 2000's. The ensuing gap in the 2000's remained more unstable since the CV was very high in 2000. In Sri Lanka, the average $\mathrm{I} / \mathrm{Y}$ and $\mathrm{S} / \mathrm{Y}$ were estimated to be 24.8 and 16.26 , respectively. The I/Y ratio was the $2^{\text {nd }}$ highest in the region after India in the 2000's. The savings-investment to GDP gap (S-I/Y) was zero in the 1990's, but increased to 8.51, thereby showing that during the 2000's Sri Lanka was more dependent on other sources to finance this gap and that the relationship between savings and investment was weak.

India is the only country where the saving-investment gap remained lowest during the 1980's and 1990's. In fact, this gap decreased to 1.6 in the 2000's. This showed that domestic savings were financing most of the domestic investment and dependence on foreign capital was relatively low in India. In Pakistan, the saving-investment gap increased over time and reached 11\% during the 1990's, the highest in the region during this time. However, it decreased to 1.81 during the 2000 's, the $2^{\text {nd }}$ lowest in the region after India. Sri Lanka's saving-investment gap increased in the 1980's and was highest in the region during this decade, which deceased in the 1990's. It, however, increased in the 2000's. Bangladesh is the only country for which the saving-investment gap decreased over time. It increased in the 1980's but reduced considerably each decade with an average of only 5.7 in the 2000's.

\section{Methodology and Data Source}

\subsection{The Saving-Investment Approach}

Feldstein and Horoika (1980) utilized the following equation for the panel of OECD countries 


$$
(\mathrm{GGDI})_{\mathrm{it}}=\alpha+\beta(\mathrm{GDS})_{\mathrm{it}}+\varepsilon_{\mathrm{it}}
$$

The GGDI is the ratio of gross domestic investment to GDP; GDS is the ratio of gross domestic saving to GDP. The null hypothesis of perfect capital immobility is not rejected if $\beta$ is not significantly different from one and rejected if $\beta$ is not different from zero. Equation (1) has been estimated for a panel of five countries (i.e., Pakistan, India, Bangladesh Sri Lanka and Nepal). This equation was estimated using the ordinary least square (OLS) method. Regressions were also estimated by other panel data techniques such as the fixed effect and least square dummy variable techniques. In this study, an effort was made to remove some of the econometric issues raised in the literature by incorporating remedial measures to make this approach more applicable for the study sample.

\subsection{Criticism to F-H Approach and Possible Remedial Measures}

Dooley et al. (1987), Bayoumi (1990), Feldstein (1983), and Feldstein and Horoika (1980) explained the problem that saving and investment are both strongly pro-cyclical in nature even when in the form of ratio to GDP. If both factors increase due to an exogenous shock, the correlation cannot be attributed to low capital mobility. For this reason, growth rate of GDP is used as an explanatory variable. This handles possible specification bias due to a single variable equation (Dooley, Jeffery, \& Donald, 1987). However, its inclusion may reduce the correlation of savings coefficient. The other common issue is the endogeniety problem. The government reacts to a trade deficit induced by an increase in investment by cutting government expenditures or raising taxes. The endogeniety is created by correlating saving and investment for reasons other than capital mobility. In order to dismantle the endogeniety problem, Dooley et al. (1987) and Bayoumi (1990) used instrumental variables which affect saving, but were irrelevant for investment. For the current study, savings lag is used as an instrument.

Thus, the following equation will be estimated after the inclusion of growth rate of GDP:

$$
G G D I_{i t}=\alpha_{i t}+\beta_{1} G D S_{i t}+\beta_{2} G G_{i t}++\varepsilon_{i t}
$$

The GG abbreviates the growth rate of panel countries. Openness is another relevant variable suggested by Kim (1993).This study has used imports to GDP ratio (Imports/GDP, IMP) as a proxy of openness. After the inclusion of openness, the following regression equation will be estimated:

$$
G G D I_{i t}=\alpha_{i t}+\beta_{1} G D S_{i t}+\beta_{2} G G_{i t}+\beta_{3} I M P_{i t}+\varepsilon_{i t}
$$

The selected South Asian countries have introduced liberalization policies and opened their economies in 1990's. First, the fundamental FH equation will be estimated. Afterwards, country dummies for intercept and slope will be separately introduced and incorporated in the regression. Another dummy for the post-liberalization period has been used (i.e., with a value of one after 1993 and zero before 1993).

$$
G G D I_{i t}=\alpha_{1}+\beta_{1} G D S_{i t}+\beta_{2} G G_{i t}+\beta_{3} I M P_{i t}+\alpha_{2} D 93+\varepsilon_{i t}
$$

All the variables are in shape of panel data, pooling cross section and time series of five countries. GGDI represents the ratio of gross domestic investment to GDP; GDS represents the ratio of gross domestic Savings to GDP; $\alpha_{2} D 93$ is a slope dummy interacting with GDS with a value of one after 1992 and zero otherwise.

\subsection{Real Interest rates Differentials Hypothesis (RIPH):}

The RIPH states that "if the agents make their forecasts using rational expectations and arbitrage forces are free to act in the goods and asset markets, the real interest rates among countries will equalize". However, the empirical literature does not offer a conclusive answer regarding the existence of real interest rate differentials (RIDs). Ferreira et al. (2007) concluded that RIDs are short-lived and mean reverting but different from zero long term. In this paper the RIDs methodology incorporated by Ferreira et al. (2007) will be applied to our sample of South Asian countries, with some modifications. Ferreira et al. (2007) estimated RIDs between two countries and applied modern unit root tests to check the stationary of the differential. Panel data for five countries will be used. Quarterly data from 1980 - 2008 on low risk interest rates and Consumer Price Index (CPI) was compiled for five South Asian countries. This study will use (IPS) and (LLC) and Hadri panel unit root tests to check the null hypotheses of a unit root. Theoretically, if agents make their forecasts rationally and arbitrage forces in goods and assets markets are working, real interest parity holds true (Ferreira et al, 2007). The arbitrage forces are formalized by uncovered interest parity (UIRP) and relative purchasing power parity (PPP) conditions mentioned in the following equations:

$$
\begin{gathered}
i_{i t}-i_{i t}^{*}=d s_{i t}^{e} \quad \text { Where, } i=1,2 \ldots \mathrm{N} \text { and } t=1,2 \ldots \mathrm{T} \\
d s_{i t}=\pi_{i t}-\pi_{i t}^{*} \\
d s^{e}{ }_{i t}=d s_{i t}+\varepsilon_{i t}
\end{gathered}
$$

If PPP holds true, one can substitute Equation 9 in to 10 and after manipulation, derive the following equation:

$$
i_{i t}-i_{i t}^{*}=\pi_{i t}-\pi_{i t}^{*}
$$




$$
\left(i_{i t}-\pi_{i t}\right)-\left(i_{i t}^{*}-\pi_{i t}^{*}\right)=r i d_{i t}=\varepsilon_{i t}
$$

The $r i d_{i t}$ may follow the following stochastic process:

$$
\mathrm{rid}_{i t}=a_{0}+a_{1} \text { rid }_{i t-1}+\varepsilon_{i t}
$$

The purpose of present study is to check the stationarity) of RID series by applying Panel Unit Root tests. Stationary RIDs series imply the convergence of real interest rates differentials, hence integration of financial markets. This is the first study to estimate RIDs with panel unit root techniques for South Asian countries.

The LLC test assumes that the persistence parameters are the same across cross sections. It means that $\psi_{i}=\psi$ for all $i$. Alternatively, IPS allows $\psi$ to vary across all cross sections. The LLC model allows for fixed effects and unit specific time trend along with common time effects. The structure of their model is listed below:

$$
\Delta y_{i t}=\alpha_{i}+\delta_{i} t+\theta_{t}+\rho_{i} y_{i, t-1}+\xi_{i t,} \quad \mathrm{i}=1,2 \ldots \mathrm{N}, \mathrm{t}=1,2 \ldots \mathrm{T}
$$

The unit specific fixed effect is important to capture heterogeneity since the coefficient of lagged dependant variable is homogeneous across all cross sections in equation 15. The LLC tested the null hypothesis: $H_{0:} \rho_{i}=0$ for all $\mathrm{i}$ against the alternative $H_{A}: \rho_{i}=\rho<0$ for all $\mathrm{i}$. The LLC test assumes that errors are independent across all cross sections (Banerjee, 1999). Im, Pesaran and Shin (1997) extended the LLC framework by allowing heterogeneity in $\rho_{i}$ under an alternative hypothesis. A separate Augmented Dickey Fuller (ADF) regression was first specified for each cross section, and average t-statistics for $\rho_{i}$ from individual ADF regressions were made. The IPS test requires specification of the lags and deterministic component for each cross section in their separate ADF regressions.

The Lagrange Multiplier tests of Hadri (2000) have different null hypothesis than other panel unit root tests. It says that all unit roots are stationary, which is contrary to LLC and IPS. This is similar to univariate KPSS tests, and the test statistic is distributed standard normal under the null hypothesis. In the current study, comparison of the results from all three types of tests will be interesting to estimate. This will enable overall comparison of cross section results and furthermore, the opposite null hypothesis will provide strong evidence if estimated results are similar.

\subsection{Data Source}

The main data source for this study is International Finance Statistics (IFS) by International Monetary Fund's (IMF), and Global Development Finance (GDF) by World Bank. Five countries are included in the sample (i.e., South Asia, Pakistan, India, Bangladesh, Sri Lanka and Nepal). Data used ranges from 1970 - 2006 in time series. In addition, five countries are used for cross sectional purposes.

The variables of Gross Domestic Savings and Investments are divided with the Gross Domestic Product. The data pertaining to imports of goods and services is also divided with the GDP. Data from all countries is reported in millions of U.S. dollars. Furthermore, data is derived from the same source for consistency.

Interest rates and Consumer Price Index (CPI) data were taken from IFS (2009) CD. Interest rates are low risk rates which consisted mostly of Treasury bill rate (TB), Call Money rates and deposit rates. In this study, the TB rate was used for countries such as the U.S.A., U.K., Singapore, Sweden, Malaysia, Germany, Canada, Japan and Sri Lanka. The Call Money rate was used for Pakistan and Indonesia. Deposit rates and bank rates were used for China and India, respectively. The interest rates data and CPI are from 1980-q1 to 2008-q2. This data provides enough panel data to estimate Panel Unit Root tests.

\section{Estimation and Results}

\subsection{FH Model and its Extension:}

The main results of FH (1980) and the extended model are presented in Table 2. Using data from the period 1970-2006 for five cross sections, 185 observations were obtained using Panel data techniques. First of all, the original FH model (1980) is reported, model 1 (row 1). The savings coefficient is estimated to be highly significant and its value is almost 0.60 . The FH model explains almost $50 \%$ of variations due to one explanatory variable. In a second attempt, the fixed effect model was used which resulted in a significant increase in the savings coefficient. The original FH model with GDS (-1) was estimated first as an instrument with the Least squares form and then with the Fixed effect form. The coefficient of savings ranged among 0.6 to 0.8 and $t$ values remained very high in the FH and its extended models.

Because the original FH model is subject to specification bias, it has been criticized in the literature. GDP growth rate (GG) was incorporated in the original FH model. The size of GDS significantly decreased to 0.71 when compared to 0.76 in model 2 with the inclusion of GG. The sign of GG is positive implying that higher growth rate brings positive change in the GDI. The R-Sq increased from 0.60 to 0.62 . The savings coefficient significantly increased to 0.75 when Panel 2SLS was applied in model 6. The t values of the variables and overall R-square decreased. Of noteworthy importance, most of the regressions utilized in this study used the fixed effect model. 
Dooley (1987) mentions the importance of the Imports to GDP ratio (IMP) variable since it captures the effect of openness. Thus, the IMP variable was incorporated into the FH model after adding the GG variable. There was a significant change in the results of model 7 (row 7). The size of GDS significantly decreased to 0.46 . The GG variable was not significant even at $10 \%$. The IMP coefficient is highly significant with a positive sign. GDS significantly explains variations in GDI, however, when additional variables are added in the original FH model, the size of GDS decreased from 0.80 to 0.46 . The adjusted R-Sq is estimated at 0.88 , a very high value when this model is used. The savings coefficient further decreased to 0.4 when the same model is estimated with Panel 2 Stage Least Square (2SLS) (model 8, row 8). The GG variable becomes significant with a positive sign. The IMP coefficient increased but its $t$ value decreased. When the same model is estimated in ordinary form, the savings coefficient was estimated to be 0.6 . The size of the GG coefficient and its $t$ value increased. The size of the IMP coefficient and its $t$ value decreased but was remained highly significant. The savings coefficient ranges from 0.4 to 0.8 , depending on the model specification. In the original FH model, the savings coefficient is estimated to be close to 0.8 but with the addition of GG and IMP, the size was significantly reduced. The savings coefficient remains high (i.e., 0.8), even when Panel -2SLS was applied in single variable regression. However, in the presence of GG and IMP the savings coefficient decreases to 0.4 with the Panel 2SLS model. Higher growth rate and openness are estimated to be positively related to GDI. In order to capture the effect of liberalization and openness policies, a dummy variable was incorporated (i.e., with a value of one after 1993 and zero otherwise). According to Bekaert, Harvey and Lundblad (2000) most South Asian countries started liberalization in the early 1990's. Pakistan's Liberalization date is 1991 where as it is 1992 for India and Sri Lanka.

The results are shown in row 10 of Table 1. The dummy variable showed no significance, however, all other variables were significant. The coefficient of GDS is 0.6 which implies that almost $60 \%$ of the GDI has been estimated to be financed by GDS. The overall results remained nearly the same when the model was estimated using the Panel 2SLS (Model 11).

It is also important to find change in the slope of GDS in the post liberalization period. A slope dummy was incorporated into model 12 (row 12). The model shows a significant negative slope dummy, which may imply that the relationship between domestic savings and investment weakened in the post-liberalization period. It further provides evidence in favor of increased integration after the 1990's. The overall intercept and intercept dummy after 1993 are both insignificant.

The $\mathrm{R}^{2}$, estimated at 0.91 , is high. The overall results support the moderate degree of integration which increased in the post-liberalization period, shown in Model 12. However, according to Model 11, no significant structural shift has been observed after 1993 period.

\subsubsection{Cross section Dummies and FH model:}

It is important to estimate the cross section intercept and slope dummies for this model. This information provides important information about differences in cross section behavior. The results are reported in Table 3. Model 1 has an overall intercept with four intercept dummies (Nepal excluded). This model does not have overall GDS; therefore, it contains five slope dummies. Model 2 has both the overall intercept and GDS variables with dummies, excluding Nepal. In Model 3, GG and IMP variables were added. In model 1, the intercept dummy is significant for three countries (i.e., Pakistan, Bangladesh and Sri Lanka). Overall and India's intercept dummy is not significant. There was nearly one slope dummy for India, 0.80 for Bangladesh and 1.5 for Nepal. However, the slope dummy is insignificant for Pakistan and Sri Lanka, which may imply a higher degree of integration since intercept dummies are both positive and significant $\left(\mathrm{R}^{2}=0.70\right)$.

In model 2, Nepal is excluded to avoid the dummy variable trap. Interestingly, the overall results remain the same. The cross section slope is derived by adjusting the cross section slope coefficient with the overall GDS, which is significant at a value of 1.50. The slopes for India, Bangladesh, Pakistan and Sri Lanka were nearly one, 0.80, 0.08, and 0.25 , respectively. The intercept is significant in for Pakistan, Sri Lanka and Bangladesh. This finding supports the hypothesis that the degree of integration is higher in Pakistan and Sri Lanka. There is some degree of integration in Bangladesh. Surprisingly, India is not integrated with world financial markets, although it received the largest capital flows in the region. In model 3, two more explanatory variables have been added (i.e., GG and IMP). Four intercept and five slope dummies were incorporated. Results showed that none of the cross section countries estimated GDS close to a value of one. Bangladesh, however, had a slope dummy of 0.62. India and Nepal showed moderate degrees of integration. Pakistan and Sri Lanka had degrees of integration of 0.3 and 0.2 , respectively.

In conclusion, when the original FH model is used, the relationship between GDI and GDS is estimated to be higher (i.e., 0.80). However, when other important variables are included in the model, dummy variables and the size of the GDS coefficient significantly decreases, which casts doubt on the original FH model with one variable regression. 
The dummy variable for the post-liberalization period implies that over time, South Asia integrated with the world although the degree of integration may vary across countries.

\subsection{Real Interest Parity and integration}

Panel Unit root techniques were applied to check the hypothesis that the real interest rate differentiates among Asian countries along with the USA, Canada, UK, Germany, Netherlands, Sweden, Australia, South Korea, Indonesia, Malaysia, Singapore, China and Japan. It is said that generally the power of unit root tests is low if the number of observations are also low. In this study, three panel unit root methods were applied: Levin, Lin and Chu (LLC), Im, Pesaran and Shin (IPS) and Hadri tests.

Table 4 shows that for most of the cases (i.e., Australia, Canada, Germany, UK, USA, Indonesia, Korea, Malaysia and Singapore), RIDs have been shown to be stationary at the first difference, integrated for order one using two techniques: Hadri and LLC. However, IPS tests show the RIDs of South Asia with these countries stationary at levels. In China, LLC and IPS show that RIDs is non-stationary at levels but the Hadri test shows it to be stationary at levels. For Sweden and the Netherlands, the LLC and IPS tests provide evidence of stationarity at levels, but the Hadri test showed them to be integrated on an order of one. Japan was the only country that showed RIDs series to be integrated on an order one. The null hypothesis of a unit root with Hadri and LLC for nine countries was not rejected at levels since the computed probabilities for most of the cases were $>0.05$. However, the null hypothesis of unit root was rejected for South Asia since the probability was nearly zero at first difference.

The results of this study strongly support the hypothesis of financial integration. Real interest rate differentials are shown to be stationary and short-lived for most of the cases. The order of integration may be different for some countries using the three techniques. This implies that the financial markets of major South Asian countries are integrated with the USA, UK, Canada, Sweden, Germany, South Korea, Malaysia, Indonesia, Singapore, Japan and China, major developed and emerging economies of the world.

\section{Conclusion:}

This study estimates the degree of financial integration in a panel of five South Asian countries by applying two econometric techniques (i.e., savings investment relation and real interest rate differential condition). The overall GDS coefficient is estimated to be between 0.8 and 0.4 , which may imply some degree of integration. The post-liberalization dummy variable showed a reduction in the size of GDS which can be interpreted as increased integration with the initiation of the liberalization process in South Asia in the 1990's. The degree of integration may vary across countries. The real interest differential model when applied provides evidence in favor of a high degree of financial integration in South Asian countries. The result is consistent with panel unit root methods such as Hadri, IPS and LLC.

The interesting aspect of this study is its objective to find evidence of financial integration with saving investment technique, considered to be a method of estimating low integration and capital mobility. Integration was detected after adding Growth rate of GDP and Imports to GDP ratio as explanatory variables to the FH model. Furthermore, after estimating the model with Panel 2SLS using the lag of GDS as an instrument, the results remained consistent. Since the saving investment relationship technique requires real interest parity to hold (Frankel, 1992), estimates strongly support that the real interest parity holds true for a panel of major South Asian countries that are major economic contributors to the world. The empirical evidence with real interest rate parity provides stronger evidence of integration when compared to the savings investment technique which provides moderate evidence. Hence, the FH savings investment model remains to be clarified for South Asian countries.

\section{References}

Adedeji, O. \& Thornton, J. (2007). Saving Investment and Capital Mobility in African Countries. Journal of African Economics , 16 (3), 393-405. doi:10.1093/jae/ej1039, http://dx.doi.org/10.1093/jae/ej1039

Banerjee, A. (1999). Panel Data Unit Roots and Cointegreation: An Overview. Oxford Bulletin of Economics and Statistics .

Baxter, M. \& Urban, J. J. (1997). The International Diversification Puzzle is Worse than you Think. American Economic Review , 87, 170-80.

Bayoumi, T. (1990). Saving Investments Correlation: Immobile Capital Government Policy or Endogenous Behavior. IMF Staff Papers , 37.

Bekaert, G., Harvay, C. R., \& Lundblad, T. C. (2001). Emerging Equity Markets and Development. AFA 2001 New Orleans Meetings, Fuqua Working Paper, 49. 
Chakrabarti, A. (2006). The Saving-Investment relationship revisited: New evidence from multivariate hetrogeneous panel cointegration Analysis. Journal of Comparative Economics , 34 (2), 402-419.doi:10.1016/j.jce.2006.02.001, http://dx.doi.org/10.1016/j.jce.2006.02.001

Coakley, F. J., \& A.-M, S. F. (2001). The Feldstein Horoika puzzle is not as bad as you think. Discussion Paper in Economics-BIRBECK COLLEGE.

Cooray, A., \& Sinha, D. (2007). The Feldstein-Horoika model re-visited for African countries. Applied Economics , 39 (2), 1501-1510. doi:10.1080/00036840600675679, http://dx.doi.org/10.1080/00036840600675679

Dooley, M., Jeffery, F., \& Donald, M. J. (1987). International Capital Mobility: What Do Saving Investment Correlation Tell Us. IMF Staff Paper, 31.

Edison, H. J., \& Pauls, D. B. (1993). Reassessment of the Relationship Between Real Exchange Rate and Interest Rates: 1974-1990. Journal of Monetary Economics, 31 (2), 165-87. doi:10.1016/0304-3932(93)90043-F, http://dx.doi.org/10.1016/0304-3932(93)90043-F

Engel, C., \& Kenneth, K. (1989). Savings and Investments in an Open Economy with Non-Traded Goods. International Economics Review , 30, 735-52. doi:10.2307/2526749, http://dx.doi.org/10.2307/2526749

Feldstein, M. (1983). Domestic Savings and International Capital Movement in the Longrun and the Shortrun. European Economic Review .

Feldstein, M., \& Charles, H. (1980). Domestic Savings and International Capital Flows. Economic Journal .

Frankel, J. A. (1992). Measuring International Capital Mobility: A Review. American Economic Review .

Ferreira, A. L., \& Leon-Ledesma, A. M. (2007). Does the real interest parity hypothesis hold? Evidence from developed and emerging markets. Journal of International Money and Finance, 364-382. doi:10.1016/j.jimonfin.2006.11.003, http://dx.doi.org/10.1016/j.jimonfin.2006.11.003

Goldberg, G. L., Lothian, R. J., \& Okunev, J. (2003). Has International Financial Integration Increased? Open Economies Review , 14 (3), 299-317. doi:10.1023/A:1023939321279, http://dx.doi.org/10.1023/A:1023939321279

Government of Pakistan. (Varrious Issues). Economics Survey, Islamabad, Economic Advisor Wing; Finance Division.

Hadri, K. (2000). Testing for Stationarity in Hetrogenous Panel Data. Econometrics Journal, 148-61.

International Monetary Fund. (Various Issues). International Financial Statistics. DC: IMF. doi:10.1111/1368-423X.00043, http://dx.doi.org/ 10.1111/1368-423X.00043

Haque, N. U., \& Montiel, P. (1990). Capital mobility in developing countries-Some empirical tests. IMF Working Papers $90 / 11$.

Hussain, I., \& Jun, K. W. (1992). Capital flows to South Asia and ASEAN countries: trends, determinants and policy implications. DC: World Bank, WPS no. 842.

Im, S. K., Pesaran, M. H., \& Shin, Y. (2003). Testing for unit roots in hetrogenous panel. Journal of Econometrics, 53-74. doi:10.1016/S0304-4076(03)00092-7, http://dx.doi.org/10.1016/S0304-4076(03)00092-7

Levin, A., Lin, C.-F., \& Chu, C.-S. J. (2002). Unit root tests in panel data: asymptotic and finite-sample properties. Journal of Econometrics , 1-24. doi:10.1016/S0304-4076(01)00098-7, http://dx.doi.org/10.1016/S0304-4076(01)00098-7

Mancuso, J. A., Goodwin, K. B., \& Grennes, J. T. (2003). Non-Linear Aspects of Capital Markets Integration and Real Interest Rate Equalization. International Review of Economics and Finance, 1 (12), 283-303. doi:10.1016/S1059-0560(03)00019-4, http://dx.doi.org/10.1016/S1059-0560(03)00019-4

Meese, R., \& Rogoff, K. (1988). Was it Real? The Exchange Rate Interest Differential Relation Over the Modern Floating Rate Period. The Journal of Finance, 43 (4), 933-48. doi:10.2307/2328144, http://dx.doi.org/10.2307/2328144

Montiel, P. J. (1994). Capital Mobility in Developing Countries: Some Measurement Issues and Emperical Tests. World Bank Economic Review , 8 (3). doi:10.1093/wber/8.3.311, http://dx.doi.org/10.1093/wber/8.3.311

Obsfeld, M., \& Taylor, M. A. (2002). Globalizationa and Capital Markets. National Bureau of Economic Research (Working Paper Number 8846).

Sinn, S. (1992). Saving Investment Correlation and Capital Mobility on the Evidence from Annual Data. The Economic Journal . 
Yamori, N. (1995). The relationship between domestic savings and investment: The Feldstein Horoika test using Japanese data. Economics Letters , 361-366. doi:10.1093/wber/8.3.311, http://dx.doi.org/10.1093/wber/8.3.311

Table 1 Savings Investment to GDP ratios in South Asia

\begin{tabular}{|c|c|c|c|c|c|c|}
\hline Country & $\mathrm{S} / \mathrm{Y}$ & CO- VAR. & $\mathrm{I} / \mathrm{Y}$ & CO- VAR. & $\mathrm{S}-\mathrm{I} / \mathrm{Y}$ & CO- VAR \\
\hline \multicolumn{7}{|l|}{$1970 \mathrm{~s}$} \\
\hline Bangladesh & 7 & 29.64 & 15 & 24.72 & -8 & -22.78 \\
\hline India & 19 & 5.69 & 20 & 7.15 & -1 & -89.64 \\
\hline Nepal & 9 & 32.65 & 14 & 23.47 & -4 & -66.71 \\
\hline Pakistan & 11 & 8.52 & 17 & 8.39 & -6 & -9.05 \\
\hline Sri Lanka & 13 & 7.51 & 19 & 23.47 & -6 & -66.71 \\
\hline \multicolumn{7}{|l|}{$1980 \mathrm{~s}$} \\
\hline Bangladesh & 10 & 11.16 & 20 & 5.24 & -10 & -14.28 \\
\hline India & 20 & 3.75 & 22 & 3.23 & -2 & -5.67 \\
\hline Nepal & 11 & 4.14 & 19 & 23.47 & -8.0 & -21.28 \\
\hline Pakistan & 8 & 8.56 & 16 & 10.76 & -8 & -26.47 \\
\hline Sri Lanka & 13 & 4.98 & 13 & 21.2 & -12 & -21.28 \\
\hline \multicolumn{7}{|l|}{$1990 \mathrm{~s}$} \\
\hline Bangladesh & 13 & 6.81 & 19 & 3.79 & -6 & -8.62 \\
\hline India & 21 & 1.82 & 23 & 1.46 & -2 & -24.75 \\
\hline Nepal & 12 & 10.49 & 22 & 7.22 & -10 & -4.54 \\
\hline Pakistan & 8 & 6.3 & 19 & 0.55 & -11 & -4.73 \\
\hline Sri Lanka & 15 & 7.13 & 15 & 7.22 & -0.07 & -4.54 \\
\hline \multicolumn{7}{|l|}{$2000-2006$} \\
\hline Bangladesh & 17.8 & 3.2 & 23.7 & 2.94 & -5.7 & -10.83 \\
\hline India & 26.96 & 11.86 & 28.6 & 14.15 & -1.67 & -53.43 \\
\hline Nepal & 10.9 & 22.6 & 23.6 & 9.9 & -12.74 & -23.6 \\
\hline Pakistan & 16.03 & 8.3 & 17.8 & 10.7 & -1.81 & -175.39 \\
\hline Sri Lanka & 16.26 & 6.6 & 24.8 & 12.44 & -8.51 & -25.53 \\
\hline
\end{tabular}


Table 2. Saving Investment Model for South Asia

\begin{tabular}{|c|c|c|c|c|c|c|c|c|}
\hline Form & Method & C & GGDS & GG & IMP & D93 & DS93 & $R^{\wedge} 2$ \\
\hline \multirow[t]{2}{*}{ Ordinary } & Panel-LS & $11.42 *$ & $0.62 *$ & & & & & 0.5 \\
\hline & & [16.28] & [13.18] & & & & & \\
\hline \multirow[t]{2}{*}{ Fixed Effect } & Panel-LS & $9.6^{*}$ & $0.76^{*}$ & & & & & 0.6 \\
\hline & & {$[-10.4]$} & [12.10] & & & & & \\
\hline \multirow[t]{2}{*}{ Ordinary } & Panel-2SLS & $11.41 *$ & $0.63^{*}$ & & & & & 0.5 \\
\hline & & [14.91] & [12.17] & & & & & \\
\hline \multirow[t]{2}{*}{ Fixed effect } & Panel-2SLS & $9.13 *$ & $0.80 *$ & & & & & 0.6 \\
\hline & & {$[9.16]$} & [11.21] & & & & & \\
\hline \multirow[t]{2}{*}{ Fixed Effect } & Panel-LS & $9.08 *$ & $0.71 *$ & $0.27^{*}$ & & & & 0.63 \\
\hline & & {$[10.4]$} & [11.6] & [3.31] & & & & \\
\hline \multirow[t]{2}{*}{ Fixed Effect } & Panel-2SLS* & $8.61 *$ & $0.75^{*}$ & $0.26^{* *}$ & & & & 0.62 \\
\hline & & {$[8.84]$} & [10.30] & [2.96] & & & & \\
\hline \multirow[t]{2}{*}{ Fixed Effect } & Panel-LS & $2.11^{*}$ & $0.46^{*}$ & 0.08 & $0.51^{*}$ & & & 0.88 \\
\hline & & [3.67] & [13.20] & [1.69] & [20.18] & & & \\
\hline \multirow[t]{2}{*}{ Fixed Effect } & Panel-2SLS & $2.57^{*}$ & $0.42 *$ & $0.09 * * *$ & 0.52 & & & 0.88 \\
\hline & & {$[4.06]$} & [9.50] & {$[[1.90]$} & [19.23] & & & \\
\hline \multirow[t]{2}{*}{ Ordinary } & Panel-2SLS & $6.06^{*}$ & $0.59 *$ & $0.15^{* *}$ & $0.24 *$ & & & 0.77 \\
\hline & & {$[9.65]$} & [16.29] & {$[2.32]$} & [14.4] & & & \\
\hline \multirow[t]{2}{*}{ Ordinary } & Panel-LSDV & $5.86^{*}$ & $0.61^{*}$ & $0.15^{* *}$ & 0.24 & -0.13 & & 0.8 \\
\hline & & {$[9.41]$} & [16.11] & [2.30] & [14.04] & {$[-0.28]$} & & \\
\hline \multirow[t]{2}{*}{ Ordinary } & Panel-2SLS & $5.95^{*}$ & $0.60^{*}$ & $0.15^{* *}$ & $0.23 *$ & -0.25 & & 0.8 \\
\hline & & [8.83] & [14.17] & [2.28] & [13.70] & {$[-0.50]$} & & \\
\hline \multirow[t]{2}{*}{ Fixed Effect } & Panel-2SLS & -0.7 & $0.62 *$ & 0.04 & $0.60 *$ & -0.88 & -0.09 & \\
\hline & & {$[-0.80]$} & [11.52] & {$[1.06]$} & [18.76] & {$[-0.88]$} & {$[-1.99]^{* *}$} & 0.91 \\
\hline
\end{tabular}

Note: $* * *, * *$ denote significance at 1,5 and 10 percent respectively. 
Table 3 Dummy variables and FH model

\begin{tabular}{|c|c|c|c|c|c|c|c|c|}
\hline Countries & C & GDS & C & GDS & C & GDS & IMP & GG \\
\hline \multirow[t]{2}{*}{ Pakistan } & $13.75^{*}$ & 0.08 & 13.75 & -1.43 & 1.94 & $0.27^{*}$ & & \\
\hline & {$[6.42]$} & [1.2] & {$[6.32]$} & {$[-7.73]^{*}$} & [1.3] & [5.34] & & \\
\hline \multirow[t]{2}{*}{ India } & -3.21 & $1.08^{*}$ & -3.21 & -0.43 & $4.27 *$ & $0.50^{*}$ & & \\
\hline & {$[-1.24]$} & {$[24.72]$} & {$[-1.01]$} & {$[-2.30]^{* *}$} & {$[2.95]$} & [8.38] & & \\
\hline \multirow[t]{3}{*}{ Sri Lanka } & $16.20^{*}$ & 0.27 & $16.19^{*}$ & & -2.02 & 0.18 & & \\
\hline & {$[3.74]$} & {$[0.98]$} & {$[5.36]$} & -1.24 & {$[-0.73]$} & {$[1.22]$} & & \\
\hline & & & & {$[-5.52]^{*}$} & & & & \\
\hline \multirow[t]{2}{*}{ Bangladesh } & $5.81 * *$ & $0.81^{*}$ & $5.8^{*}$ & -0.7 & 0.2 & $0.62 *$ & & \\
\hline & [2.9] & {$[16.5]$} & {$[3.12]$} & {$[-4.33]^{*}$} & {$[0.14]$} & [16.9] & & \\
\hline \multirow[t]{2}{*}{ Nepal } & $13.8^{*}$ & $1.5^{*}$ & & & & $0.5^{*}$ & & \\
\hline & {$[6.42]$} & [8.81] & & & & {$[4.2]$} & & \\
\hline \multirow[t]{2}{*}{ Overall } & 2.93 & & $2.93 * * *$ & $1.5^{*}$ & $2.61 * *$ & & $0.5^{*}$ & 0.04 \\
\hline & {$[1.50]$} & & {$[1.8]$} & {$[10.52]^{*}$} & {$[2.3]$} & & [12.85] & {$[0.74]$} \\
\hline Model No. & 1 & & 2 & & 3 & & & \\
\hline $\mathrm{R}^{\wedge} 2$ & 0.71 & & 0.71 & & 0.9 & & & \\
\hline
\end{tabular}

$*, * *, * * *$ denote significance at 1,5 and 10 percent respectively. 
Table 4 Stationarity of Real interest rate differentials

\begin{tabular}{|c|c|c|c|c|c|c|}
\hline RIDS & Hadri & & LLC & & IPS & \\
\hline & Null: Stationarity & & Unit root (common) & & Unit root(individual) & \\
\hline & level & 1st diff & Level & 1st diff & level & 1st diff \\
\hline \multirow[t]{2}{*}{ SA-Australia } & 2.64 & -1.6 & -0.93 & -13.34 & -3.2 & \\
\hline & {$[0.004]$} & {$[0.9]$} & {$[0.2]$} & {$[0.00]$} & $(0.0005]$ & \\
\hline \multirow[t]{2}{*}{ SA-Canada } & 6.4 & -0.6 & 0.67 & -14.87 & -1.91 & \\
\hline & {$[0.00]$} & {$[0.72]$} & {$[0.74]$} & {$[0.00]$} & {$[0.03]$} & \\
\hline \multirow[t]{2}{*}{ SA-China } & 0.87 & & -0.83 & -15.74 & -2.9 & \\
\hline & {$[0.19]$} & & {$[0.20]$} & {$[0.00]$} & {$[0.002]$} & \\
\hline \multirow[t]{2}{*}{ SA-Germany } & 6.28 & -1.2 & -0.87 & -1.9 & -3.18 & \\
\hline & {$[0.00]$} & {$[0.87]$} & {$[0.2]$} & {$[0.03]$} & {$[0.0007]$} & \\
\hline \multirow[t]{2}{*}{ SA-Indonesia } & 2.44 & -1.85 & -0.04 & -1.74 & -2.57 & \\
\hline & {$[0.007]$} & {$[0.96]$} & {$[0.48]$} & {$[0.04]$} & {$[0.005]$} & \\
\hline \multirow[t]{2}{*}{ SA-Japan } & 10.5 & -0.85 & 3.8 & -3.7 & -0.77 & -17.2 \\
\hline & {$[0.00]$} & {$[0.80]$} & [0.99] & {$[0.000]$} & {$[0.22]$} & {$[0.00]$} \\
\hline \multirow{2}{*}{ SA-Korea } & 6.4 & 0.5 & -1.11 & 2.63 & -5.02 & \\
\hline & {$[0.00]$} & {$[0.30]$} & {$[0.85]$} & {$[0.99]$} & {$[0.00]$} & \\
\hline \multirow[t]{2}{*}{ SA-Malaysia } & 1.5 & -0.32 & 2.43 & -10.3 & -1.9 & \\
\hline & {$[0.07]$} & {$[0.62]$} & [0.99] & {$[0.00]$} & {$[0.02]$} & \\
\hline \multirow[t]{2}{*}{ SA-Netherland } & 15.7 & -1.95 & -3.83 & & -3.5 & \\
\hline & {$[0.004] \#$} & {$[0.97]$} & {$[0.001]$} & & {$[0.00]$} & \\
\hline \multirow[t]{2}{*}{ SA-Singapore } & 6.6 & -0.2 & -0.36 & -13.86 & -1.67 & \\
\hline & {$[0.00]$} & {$[0.57]$} & [0.35] & {$[0.00]$} & [0.05] & \\
\hline \multirow[t]{2}{*}{ SA-Sweden } & 3.7 & 1.09 & -2.8 & & -3.7 & \\
\hline & {$[0.00]$} & [1.3] & {$[0.002]$} & & {$[0.00]$} & \\
\hline \multirow[t]{2}{*}{ SA-UK } & 3.61 & 0.62 & -0.5 & -12.6 & -2.3 & \\
\hline & [0.00] & {$[-0.73]$} & {$[0.31]$} & {$[0.00]$} & {$[0.01]$} & \\
\hline \multirow[t]{2}{*}{ SA-USA } & 3.5 & -0.8 & -0.4 & -13.7 & -2.43 & \\
\hline & {$[0.00]$} & {$[0.77]$} & {$[0.34]$} & {$[0.00]$} & {$[0.008]$} & \\
\hline
\end{tabular}

Note: Figures in brackets are probabilities.

The cross section results in IPS are also stationary at first difference and are not reported here for brevity, can be requested from author. 